\title{
Understanding the concept of "time" in Daniel"
}

\author{
P M Venter \\ (University of Pretoria)
}

\section{ABSTRACT}

\section{Understanding the concept of "time" in Daniel}

The temporal axis of apocalypses has always invited a wide range of interpretations. Not only dispensational schemes since the Christian era, but especially contemporary mass suicides arising from activist millennialism, points to the role of the conceptualization of time in eschatology. Mbiti's African concept of time as well as Malina's description of Mediterranean time indicate an alternative matrix for understanding time in the book of Daniel. An investigation into commentaries on Daniel shows that commentators are rather using a Western concept of time than an ancient Near Eastern concept. The need for reorientation in the time concept for studying the apocalyptic materials of Daniel is indicated

\section{INTRODUCTION}

Apocalyptic writing in the Bible and in contemporary literature is the literary product of apocalyptic groups or social movements, characterized by a dominant apocalyptic mind-set. Apocalyptic writing has:

“....a genre of revelatory literature with a narrative framework, in which a revelation is mediated by an otherworldly being to a human recipient, disclosing a transcendent reality which is both temporal, insofar as it envisages eschatological salvation, and spatial, insofar as it involves another, supernatural world..." (Collins 1996:7).

In terms of Collins' definition (1996:7) “....such a work is intended to interpret present, earthly circumstances in light of the supernatural world and of the future, and to influence both the understanding and the behavior of the audience by means of divine authority". Of importance here is the functioning of the revealed world along a temporal as well as a spatial axis.

On the spatial axis the human recipient is usually introduced to the geography of earth and heaven, and its apocalyptical meaning. Graphic artists through the ages seem to have favoured this aspect of apocalypses, portraying it in fantastic scenes of heaven and earth. On the temporal axis an impending crisis and world upheaval is projected leading to

\footnotetext{
${ }^{1}$ This paper was read at the OTTSA-SASSEM congress in Pretoria on 05-09-2000.
} 
the end of the present world. Transformation will take place in which the ungodly will be judged and the faithful believers be saved from their suffering. The temporal aspect has been the field of ideological and imaginative exploitations through the ages. Dispensational schemes, terrifying predictions and arbitrary calculations were abound in eschatological groups.

\section{THE PROBLEM}

The numbers in Biblical apocalypses, especially those referring to time, were used from early on in the Christian era to calculate the time of the end.

Adso's Letter on the Antichrist in $950 \mathrm{CE}$, started the trend in Europe to identify the so called "Last World Emperor" and his enemies in the interpreter's own contemporary society.

The Anglican bishop James Ussher published his Annals of the Old Testament, deduced from the first Origin of the World in 1650. Like Julius Africanus in his Chronografiai in $221 \mathrm{CE}$, he used a time span of 6000 years since creation and predicted the second coming of Christ in the year 2000 (cf Frontline).

Millennial dispensationalism originated with the Plymouth Brethren in the early 1830's and was introduced by John Nelson Darby in 1859 . This kind of dispensationalism forms the dominant eschatological system in present day Christianity. "Dispensational theology centers upon the concept of God's dealings with mankind being divided into (usually) seven distinct economies or 'dispensations', in which man is tested as to his obedience to the will of God as revealed under each dispensation" (Gospel Plow). Dispensationalism holds that the second Advent will be in two sections - the "rapture" and the "revelation" and in between the unfulfilled seventieth week (seven years) of Daniel 9:23-27, which they call "the Great Tribulation". When the Jews rejected Jesus the seventy weeks were suspended and the dispensation or economy of the church age began. During the Great Tribulation the events of Revelation will take place. To them Revelation 4-19 is a literal description of the events which will take place during that time. During this time the fourth worldly kingdom of Daniel, the feet of iron and clay of Daniel 2, the beast of Daniel 7, and the restored Roman empire will come as well. Dispensational premillenialism differs from classic historic premillennialism. It is a very different system of eschatology and has introduced a number of novelties in prophetic interpretation that the church never heard of until about a century ago.

Many of these ideas are found in the Scofield Reference Bible of 1909, written by C I Scofield (1843-1921), and repeated in the New Scofield Reference Bible of 1967 . These viewpoints were also advanced by Lewis Sperry Chafer (1871-1952), who established the Dallas Theo- 
logical Seminary. According to the notes in this Bible, the theory is a way of understanding the Old Testament covenants and how God will develop his kingdom program. There are specific time periods or dispensations. In each of them different responsibilities were given to man by God. The fifth dispensation is the time of the law (Moses to the cross), and the sixth the time of grace (the cross to the millennial kingdom). The literal method of interpretation is the key to this view point. It therefore presents a literal explanation of the apocalyptic literature and presents a specific set of core beliefs about God's kingdom program (cf Answers in Action).

The main issue at hand here is the exact date when the last dispensation or millennium would start. Calculations on this are done not only according to the numbers found in the Bible, but also according to different natural phenomena. The most recent example of this can be found in the expectations that the world would have come to an end on the $5^{\text {th }}$ of May 2000 when the earth, sun, moon and Mars were aligned at $08 \mathrm{~h} 00$ Universal time (cf Planetary Groupings)

Following a long history of disappointed predictions by inter alia William Miller, the founder of the Seventh Day Adventist movement, in 1843, and Charles Taze Russell, founder of Jehova's Witnesses in 1874, the age of activist millennialism started in the years seventy during the previous century. The dramatic events of creating a postmillennial kingdom on earth leading to the death of whole communities, started with the mass suicide of Jim Jones' Peoples Temple community at Jonestown, Guyana, when congressman Leo Ryan visited them on $18^{\text {th }}$ November 1978. They were followed by David Koresh and his Branch Davidians killed by fire on 19 April 1993 and the cult suicide of 39 people of Marshall Herff Applewhite's Heaven's Gate group in California during March $23^{\text {td }}$ to $26^{\text {th }} 1997$. The most recent occurrence of this phenomenon was found in Kanungu, Uganda, where 924 members of Joseph Kibweteere's doomsday religious sect, called the Movement for the Restoration of the Ten Commandments of God, died on $17^{\text {th }}$ March 2000. Kibweteere is said to have overheard a conversation between Jesus Christ and the Virgin Mary that the world would come to an end unless humans started to follow the Ten Commandments closely. This would have happened on $31^{\text {st }}$ December 1999 . The failed prophecy precipitated the mass suicide/ murder on $17^{\text {th }}$ March 2000 (cf CESNUR).

Although there were many factors which played a roll in each of these tragic events, one common factor was the expectation of an impending end of the world. This idea was created by a dispensationalist or deterministic viewpoint of world history. The literal interpretation (or what is deemed to be literal) of the apocalyptic literature of the Bible, formed the background to the different schemes developed among the different groups. The question before us is whether this understanding of 
the determinism found in Biblical apocalyptic literature is in agreement with the viewpoint in the literature itself. Isn't there a different concept of time working in these contemporary groups, which is in fact alien to the Biblical concept of time? How is time conceptualized in scholarly work, especially in the research done on Old Testament apocalyptic literature, in particular on the book of Daniel?

Time is seen as a linear process among these present day apocalypticists. The adherents of an apocalyptic system is often based on the three components of watching, waiting and worrying (cf Zahavy² 1990: no page number). The present is secondary to the future and the past in their conception. Meaning is always expressed in future terms. Something in the future is yet to come, but cannot be sought. The one who waits believes he can do little to change the course of history. He can only see the right time when the future will start. Is this the way time is perceived in Daniel? Are there other perceptions available on time?

\section{AN AFRICAN PERSPECTIVE}

Already in 1969, John S Mbiti blamed missionary teaching and the western type of education brought to Africa for destabilising African culture and bringing about future expectations leading to inter alia phenomena like those experienced in Uganda in March 2000. Introvigne (cf CESNUR 2000 no page number), in his report on the events in Uganda, remarks that scholarship about Uganda's apocalyptic movements in general warns against applying Western models to situations peculiar to Uganda. Mbiti's research into the African concept on time opens up our eyes for a totally different conceptualisation of time. The possibility of reading Biblical apocalypses from a different time orientation is enhanced by such a study of the traditional concept of time as found in Africa.

The anthropocentric ontology of the peoples of Africa is squarely based on its specific concept of time. Time is here seen as a two-dimensional phenomenon. There is a long past and a shorter present and traditionally no future. What has not taken place or what has no likelihood of immediate occurrence, falls in the category of "No-time". It has not taken place and cannot constitute time. Those events which are certain to occur, which are so immediate and certain that it is as if people have already experienced it, and which fall into the inevitable rhythm of nature, constitute potential time. It is not already actual time, but will become actual within a short while. Potential time, however, has a very short range of six months up to two years at most. It can only be an extension of the present and is only of concern where it is of service to the present experience. The idea of a future dimension brought to Africa

${ }^{2}$ Zahavy is referring to Vincent Crapanzano 1985. Waiting: The whites of South Africa. London: Granada. 
by Westerners is seen as a destabilizing force which shifts all expectation to the world of No-time and of illusions, bringing about political, economical and ecclesiastical instability (cf Mbiti 1969:221).

Time is something which has to be experienced. It is a composition of events. It is not named according to abstract dates or years, but according to the events which took place. An individual can express it in terms of the experience of childhood, puberty etcetera. A group expresses it according to events that occurred in the group, for example, the birth of a leader or a war against a rival group.

Time experienced belongs either to the present or to a longer stretch of time, which is seen as an extended past. Mbiti uses the Swahili words Sasa and Zamani, for these two dimensions of the present and the extended past. The present Sasa-time is the time region of the NOW, the conscious time, the time dimension with its own short future, dynamic present and experienced past. It is the micro time which the individual or community is experiencing all the time, forming one coherent whole. The Zamani-time forms the macro time overlapping with the Sasa time. It is the graveyard of time, the period of termination, the dimension in which everything finds its halting point. But it is not something of the past, rather historical time extended in to present time, influencing the present. "The centre of gravity for human thought and activities is the Zamani period towards which the Sasa moves" (Mbiti 1969:23). In the Zamani period an explanation about the creation of the world, the coming of death, the evolution of language and customs, and everything depicting the Sasa-time is found. As a person grows older and eventually dies, he moves from the Sasa-time to the Zamani-time. He becomes part of that long stretch of time which includes and influences the present Sasa-time. As long as people remember the deceased, he lives on in the Sasa-time, although he is already part of the Zamani-time. Shifting expectations to the future time which Christian missionaries taught and Western education brought to Africa, depletes the present time of its central role and removes the real meaning of life. It destabilizes the equilibrium of everyday life. Everyday life should be past-orientated to give meaning to life.

\section{A MEDITTERANEAN PERSPECTIVE}

Another perspective somewhat nearer in time and space to the apocalyptic literature of the Bible, is found in the studies of Bruce Malina. In 1989 Malina made a social scientific analysis of the ancient Mediterranean concept of time. He compared their view of time with the modern Western European concept of time. His conclusion was that there is a vast difference. While the modern world is future orientated, the ancient Mediterranean world, in which the Bible was created, was present orientated. There is a large difference between a pre-Einsteinian, pre- 
Industrial Revolution, pre-Enlightenment, pre-Newtonian, pre-Monastic ancient Mediterranean perception of time and the perception of time common to most contemporary readers. The first century Mediterranean eschatological and apocalyptical literature projected its contents on a temporal and spatial axis, which was present orientated in line with their unique contemporary cultural concept of time. When this literature, however, is read from a twentieth/twenty first century future orientated perception of time and space, it leads modern commentators to discover features of the future which is nothing else than "... an anachronistic and ethnocentric overlay" (Malina 1989:29).

Malina therefore proposed that the areas called "eschatology", "apocalyptic" and "delay of parousia", should be rethought from a study of what the ancient Mediterranean concept of time was. In the period when the Bible was written there was no tension between the "now" and the "not yet", like there is today. There was only emphasis on a rather broad "now". The "not yet" is only a continual concern of persons from future-orientated societies. They would read into the Biblical material futuristic meaning that was never intended. In their linear way of thinking and their industrial type of communities, time is divided into a series of detached sets of events belonging either to the present, the past or the future.

In rural societies like those of Mediterranean antiquity, a presentorientated temporal preference exists. Their "present", however, covers a broad sweep marked off only by the horizons of the imaginary past on the one side and the imaginary future on the other. What lies beyond that horizon, either in the past or the future, is imaginary time. It consists of possibilities and probabilities which lie outside human experience and human control. It contains things which can be known and decided by God only. It is the exclusive domain of God. Information on that time can only be disclosed by God through his prophets.

Between these horizons lies the present time. Over and against our abstract concept of time as an endless series of indeterminate possibilities, the ancient Mediterranean's time was “...the perception of duration solely within the perceived horizon of the world of actual experience" (Malina 1989:11). Everything experienced, being experienced and going to happen was organically related, forming one single meaningful "now". What lies ahead was not the separated (dismembered) future in our sense of the word, but rather the forthcoming. It was the organic related unfolding or developing horizon of the experienced present. It was the ongoing development of a process of social relations and social transactions. Cyclical events (like the seasons in nature) and procedural occurrences (all the events belonging to the process of living, from birth until death) enmesh in the unfolding of one overwhelming present time. Historical events are organically related to the present, contributing to 
present activity by indicating behavioural patterns and the value of specific social norms.

According to Malina (1989:28) apocalyptic literature was rather referring "... in various ways to the process by which the forthcoming was transformed into the possible for early Christian generations". It was dealing with actual, experienced time situated in an operational realm abutting on the horizon of the present. It was only in later times under the press of events that the perception of apocalyptic literature proceeded beyond the horizon of the present into the realm of the future, the possible rooted in imaginary time.

In his commentary on Revelation in 1995, Malina applied his study of ancient Mediterranean time to the book of Revelation. According to Malina, the time concern in Revelation ".... is not the remote or distant future, but the past, the present and the immediate forthcoming. And what bothered people was not the end of the world, but what forthcoming events held in store for the group" (Malina 1995:45). People reading Revelation from a modern time perspective convert the present orientated vertical prophecy of the book into a future orientated horizontal ideology of future cosmic transformation and looses sight of its intended theological meaning.

\section{TIME IN DANIEL}

\subsection{The historical and social matrix}

What Malina proposes is to read apocalyptic literature from the viewpoint of the Mediterranean concept of time as it was defined by socio scientific investigation. P D Hanson (1985:466) already said in 1985: "There is a woeful lack of attention to the social and historical matrix behind each apocalyptic work". Although much attention has been paid to the historical matrix since then, the social matrix was very much left behind. In 1994 Murphy pointed out that detailed theories about specific segments of Jewish society that developed apocalyptic outlooks were done by Plöger and Hanson. Although there are many scholars who think that there is not enough evidence to support such detailed theories, Murphy (1994:161) is of opinion that "...attempts to relate the development of apocalypticism to concrete historical circumstances are valid and must be pursued, so far as possible, for each individual apocalypse". In 1998 Collins indicated that a differentiated approach should be followed for the historical and social matrix of the genre of the apocalypse (cf Collins 1998:21). It is generated by social and historical circumstances which differs from book to book. Already in 1993, Davies expressed surprise that the enormous amount of form-critical study on Daniel, which should have paid attention to its Sitz im Leben as well, "...has yielded surprisingly little illumination of the social basis of its 
composition" (Davies 1993:348). An overview of publications on Daniel, even up to now, shows this remark to be correct. In the most recent studies and commentaries scholars have started to pay attention to the groups or social movements who wrote this literature. Real attention to the social matrix has not been paid yet. What is even more remarkable, however, is the way in which the historical matrix is treated in the best known and most used commentaries on Daniel. In the way in which the authors treat history and the issue of time in Daniel, their own conceptualisation of time becomes clear. The way in which they retell the story of Daniel shows how they understand time themselves.

\subsection{Daniel 1-12}

In his study of the different Hebrew and Aramaic words used to indicate "time" in the book of Daniel, Verhoef (1994) comes to the conclusion that all of them point to a perception of time as being appointed by God. Concepts for time are more often used in Daniel than in any other book in the Old Testament. Hebrew words like 'et, qes, mo'ed and 'olam and Aramaic words like 'alam, zeman, iddan and sha'a are used to indicate the various aspects of time, like point of time, duration of time and units of time. Read within their literary context, these words and especially those used for units of time, like day, week, and year, point to an eschatological-apocalyptic context in which time has a symbolic rather than a literal meaning. In this regard, these words in Daniel correspond with the periodisation of historical and eschatological epochs in the literature found at Qumran and the Rabbinic literature, especially so with the words qes and 'alam/ olam, which indicate the end of time. A hint at Verhoef's concept of time in eschatological context is found on his remark on the combination 'et qes in Daniel 8:17,11:35 and 12:4 and 9. According to him, all of these cases reflect a time "anderkant die geskiedkundige horison, en dit is ' $n$ ongedefinieerde en ondefinieerbare werklikheid" (Verhoef 1994:228). The Aramaic word 'alam indicates, according to Verhoef (cf 1994:230) a duration of time which surpasses earth time having no time boundary and therefore indicate Godly eternity. These remarks indicate that Verhoef interprets Daniel's eschatological time as earthly time which has an end, and eternal time which belongs to a dispensation following the end of earth's time. It is not time forthcoming but time removed to the future. Over this future time God who lives forever, has full control.

Whether such control can be seen to be deterministic is the subject of Helberg's study on Daniel in 1995. Understanding "deterministic" in a dualistic way as determining time in a mechanical, a-personal and ahistoric way so that other factors on par with God determine events, Helberg denies that any such ideas are found in Daniel. According to him the message of the book as a whole "...advocates God's full control 
of every event, his determination of everything, but not in a mechanical, deterministic way" (Helberg 1995:273). In the time of Antioch Epiphanes determination is taken to its limits and the readers are instructed "...to see God both as the supreme, determining sovereign over the heavens and the earth, and the living God who has a covenant relation with the Jewish people" (Helberg 1995:275). During their history God repeatedly overrides death making a new beginning with his people and when history reaches its climax. He will transcend ultimate death and history when his kingdom comes replacing all earthly kingdoms.

This history consists of different aeons determined by God. As this history is a closed book, man has to trust God with history and simply persevere in fellowship with God "...so that he has a future and a worthwhile present, and be able to live with his eyes fixed on the time of the end" (Helberg 1995:280). This time of the end or set times (7:25 and $8: 14,9: 24,26,27 ; 12: 7,11,12$ ) should not be interpreted punctiliously and "...does not refer to a deterministic domination of time over events, but to God's full control" (Helberg 1995:274). It is a determined point of time, but "...determined by God's will in and through history, not fatalistically. There is no mechanical course of time, nor any a-moral fatalistic decreeing of events. God's sovereignty and his covenant relation with his people determines the history of the world.

Helberg hits at the heart of the problem of determinism and dispensationalism as it is found among contemporary millenarian groups. Their dualistic viewpoint makes God ultimately dependant on the scheme he developed. Helberg's conceptualisation of time in Daniel is, however, very much dependant on a modern Christian eschatological scheme where the turning point in history forms the focus and everything is very much future orientated.

\subsection{Daniel 7:25}

Historical critical investigation has become the norm in Daniel commentaries during the last two decades. The designation in Daniel 7:25 of "time, times and half a time", the "seventy sevens" in Daniel 9:24-27 and "the time of the end" in 11:40-12:13, is understood as "...firm chronological information, which as such can be tested by chronological facts available to us" (Goldingay 1989:257). Traditional Christian interpreters apply this information to the time between Nehemia in $445 \mathrm{BCE}$ and Jesus' death at Passover in $32 \mathrm{CE}$. Critical scholars also take it literally but apply it to the time between the exile and the rededication of the temple. The "assured results" of modern historical investigation are taken as point of departure for reading Daniel. The author of Daniel has even been faulted more than once for his 'miscalculations' (cf Redditt 1999:133). The historical matrix behind Daniel is identified with the positivistic chronology of modern investigation. This can be seen in the 
way concepts of time in Daniel are defined in modern chronological terms.

The primary intention of the three and a half periods in Daniel $7: 25$ is to assure the persecuted Jews that the time of trial is coming to an end. It gives an encouraging answer to the community's question "How long?" to mean "not long" (cf Redditt 1999:132). It is the complement of Genesis 1:1's "in the beginning God" as "in the end God...". Daniel 7:25 may be read as an attempt to give a less than specific answer to the question of the time of the end, while 12:5-12 gives a specific answer, with 9:24-27 standing somewhere in between" (Reddit 1999:133). According to Collins (1984:93) this end coincides with the profanation of the temple and can be quantified in terms of modern chronology to last "...for half a week (i.e. three and a half years...)". Goldingay is not willing to take these $3 \frac{1}{2}$ periods as three and a half years. The anticipated doubling sequence of 1, 2, 4, 8 is broken off, and therefore: "It suggests a time that threatens to extend itself longer" (Goldingay 1989:181). This is a time not without end. There is a sudden termination of the reign of this king.

\subsection{Daniel 9:24-27}

Taken as ex eventu prophecy where there is a typical periodisation or division of history, Daniel 9:24-27 deals with the history of Yahweh's people in terms of three apocalyptic epochs forming a 70-yearweek period (Collins 1984, Laato 1990). These periods are calculated according to modern counting of years and historical knowledge to start with the destruction of Jerusalem in 587/6 (Lacocque 1979:194) and the return from the exile in 538, giving 7 year-weeks or 49 years. It ends with the time between the murder of Onias III at the end of the 170's and the purification of the Temple in 164 BCE (Redditt 1999:162). The problems arising from this type of calculation is shown by Laato's study. When the second epoch of 62 yearweeks is taken as 434 years, it does not fit into the slot between 538 and 170. Laato's solution to this problem is to use redactional criticism and read verse 27 as a reinterpretation during the Maccabean period of an existing tradition in 24-26 agreeing with the expectations in Zechariah 12-14. This will make it possible to understand the three epochs as already included in the first three verses.

"The first epoch stems from historical reality i.e. from the length of the Exile. The second epoch was derived from the chronology of the Deuteronomistic Historian. What remains is seven years and this is interpreted as referring to the length of the final struggle. This apocalyptic theme was then actualised during the Maccabean period" (Laato 1990:224). 
Laato therefore works with a mixture of realistic and theological chronology. He calls it an apocalyptic theme which is realized during the Maccabean time. Forcing the contents of Daniel into a modern chronology inevitably leads to a manipulation of the material.

While some commentators do work with the traditional chronology, they are investigating other avenues as well. Lacocque (1979:178) talks of a symbolic time-span of ten sabbatical cycles and says that "...Daniel announces the coming of the ultimate Jubilee, the Eschaton". The author "has a plainly priestly conception of history and eschatology" (Lacocque 1979:194) and used midrashic actualization of prophetic writings to express "the idea of a second exodus surpassing the first one ... in that it will really be eschatological" (Lacocque 1979:177).

Collins (1984) sees a difference between the deterministic, apocalyptic view of history found in Daniel 9:24-27 and the Deuteronomistic theology of the prayer in Daniel 9:4-19. He interprets the deterministic time span of seventy sevens in terms of weeks and years according to the historical critical chronology. In his work of 1998 Collins still talks of seventy weeks of years, 490 years, but does not see it as "the product of any chronological calculation" (Collins 1998:109). It is a traditional schema, an instance of "sabbatical eschatology". Daniel's main concern is not speculating on the future, or the sequential development of history, but providing an assurance that the predetermined period of Gentile sovereignty is coming to an end.

A most interesting approach is found with Goldingay (1989). Although he agrees that the periods used in 9:24-27 constitute jubilees, he remarks that the jubilee theme itself does not feature in these verses. Daniel 9:25 refers to the material restoration of Zion. Like the vision in chapter 8, Daniel 9:24 "looks forward from the time of Daniel himself to the Antiochene crisis, and promises God's deliverance" (Goldingay 1989:260). By the time the seventy sevens end, six things are to be achieved for people and sacred city. The concern is Israel and Jerusalem. "It does not have a worldwide perspective; it is not speaking of the end of all history, or of the sin of the whole world" (Goldingay 1989:258). Factual history is used in this passage, but as a background for the proclamation that God is the God of all history and of Israel's. "It is not chronology but chronography: a stylized scheme of history used to interpret historical data rather than arising from them..." (Goldingay 1989:257). These number of periods do not necessarily correspond numerically to chronological periods. If they are to be linked to chronological periods then it should be done on the basis of exegetical considerations as these arise from the passage, not of actual chronology.

Adele Yarbro Collins sees numerical symbolism as "...part of the activity of discovering order in environment and experience" (Collins 1996:56). Order is created in the experience of time as well as of space. 
Calculations in the book of Daniel are not predictions of a particular day or year, but an ordering technique to discern meaningful patterns in time, past, present and future. In Daniel 9:24-27, an ex eventu prophecy, the actual course of events between the exile and the time of Daniel had an impact on how the block of time was divided. The main issue, however, was to emphasize the nearness of the end as part of an orderly and rational world history. A sabbatical logic is used working with the number of seven in different forms. Elsewhere in apocalyptic literature the numbers 12,4 and 10 are used.

In the explanation of Daniel 9:24-27 we can therefore see how a shift is taking place away from an exclusive use of a modern chronological scheme to a rather more ideologically orientated matrix. Goldingay's proposal to interpret the time concept in apocalypses rather as chronography than chronology is very promising. Adele Yarbro Collins' investigation of numbers as an ordering technique indicates that words for time are also graphical terms used in apocalyptic literature to bring order to a world which is in crisis. The efforts to understand these words in terms of Jubilees and Sabbaths clearly indicate the direction for future investigation. They should be understood in terms of a social matrix in which time is seen as forthcoming, not as independent chronological units with no internal relationship.

\subsection{Daniel 11-12}

There is general agreement between commentators that a change takes place in Daniel 11:40. According to LaCocque (1979:232) the history has been described "accurately" up to Daniel 11:39. From then onwards the "prophecy" begins. For Goldingay (1989:305) a transition takes place in 11:40 from "quasi-prediction based on historical facts to actual prediction based on Scripture and on the pattern of earlier events". According to Towner (1984) what is told in 11:40-45 never transpired. Up to here the events were those experienced by the author in 168-7 BCE. From here onwards factual history is left behind. Because the author gets it all muddled we know that here "we are at the point at which the seer actually begins to look into the future..." (Towner 1984:165). A division is therefore made between recordable and controllable events and those which are placed in the future. And this immediately presents contemporary readers with the problem how to conceptualise a "time" which they see as detached from our present time. If Daniel talks about so called "factual history", it can be conceptualised in modern chronological terms. When future events are indicated, which are seen to be beyond our chronological horizon, our conceptualisation fails.

What this future holds in store is therefore interpreted differently by commentators, especially with regard to their conceptualisation of time 
and determinism. Collins (1984:104) does not see it as “...just a new political administration or even the restoration of the temple, but a new order where the faithful community shares the power of the heavenly holy ones and the wise teachers shine with them in eternal life". Resurrection and a new era is involved, one which is drastically different from all that has gone before. This view he repeated in 1998: "The destiny of the wise lies beyond this life in a resurrection and pertains to the world of the angels" (Collins 1998:114). Redditt (1999:193) formulates it as "retribution ...beyond the grave". Towner (1984:179) points out that a basic three part picture is used of the future which was inherited from the earlier exponents of prophetic or "realistic eschatology: the onset of last times, the crisis of the Day of Yahweh and beyond that day the restoration of right order in a redeemed and renewed world". The Old Testament moves in the same direction as the New Testament with its elaborate tableau of end time events in the form of heavenly scenes, cosmic forces, etcetera, but "does not want to move very far in that direction" (Towner 1984:173). It anyhow pictures an era beyond this world. It is something jenseitig.

LaCocque and Goldingay are inclined to understand the future as diesseitig. LaCocque (1979) concentrates on the present. In his mind the apocalypticist is not appealing to the past like the prophet, nor to the future. The "Day of the Lord", beyond which there are no more days to come, has already arrived. Therefore time is telescoped into the lived moment. "The instant fills the whole horizon" (LaCocque 1979:251). Israel finally becomes what they actually are. The future predicted in this passage is not read by Goldingay as mere anticipatory announcement of fixed future events. It rather "...paint(s) an imaginative scenario of the kind of issue that must come from present events' (Goldingay 1989:305). The time referred to indicate continuity with what precedes and it excludes the idea that he seer is moving to some far future moment. The resurrection is a vision that portrays the future on the basis of Scripture within its historical context, even clearer than that of Ezekiel 38-39. It is a vision "of life on earth lived by beings who are still human" (Goldingay 1989:309). It envisages a life of a heavenly character, the life of eternity. For Goldingay it is the end time, rather than the end of time.

Linked to this issue is the matter of determinism. Collins (1984: 102 ) is of opinion that the temporal precision in Daniel "...builds the assurance that all is predetermined, since so much can be 'predicted' accurately". Towner (1984:175) talks about "...an inexorable destiny manifest in events". Everything that happens is ordained by God. God has decided nothing new since the beginning of time. There is divine foreknowledge and prophetic access to that foreknowledge. It is his task "to project the sequence of the inexorable divine decree into the future and up to the time of the end" (Towner 1984:175). God has always 
accomplished what he has set out to do. For the writer of Daniel 10-12 what will be will be and whatever was, had to have been.

Against Towner's interpretation of Daniel as presenting history that was pre-written, Goldingay (1989:315) views human beings as "standing beneath an overarching determination of God and as responsible to him and to themselves for their destinies". Daniel, according to Goldingay, is not thinking about history in a dualistic way. God is sovereign in heaven and on earth. His purpose can be opposed and delayed but not frustrated. The real decisions about history are not made in heaven in such a way that human beings are not responsible for history. But it cannot be seen monistic as the outworking of human decisions alone: “...free human decisions unwittingly contribute to the working out of God's purpose..." (Goldingay 1989:312). "The significance of describing what is actually past history as pre-written is to declare that God is somehow in control even of the inexplicabilities of history ....and even at moments when evil is asserting itself in a particularly oppressive way" (Goldingay 1989: 315). History was foreknown by God and in some sense willed by him. "There is a fixed inevitability about history; human beings cannot frustrate God's ultimate purpose, and in that sense cannot alter what has been determined by God's will". The detailed portrayal of how the End will come is an imaginative scenario drawn in the light of Scripture, rather than a forecast of how things actually must be. Redditt (1998:193) agrees that deterministic does not mean that God determines every detail of human life, rather that what God would do and when He would, is predetermined.

When explaining the meaning of the different expressions for time, the differences once more become obvious. Towner (1984:170) hears in the use of the expression time, two times and half a time $(7: 25,9: 27)$ a writer with a sense of immanence of the eschaton'. The two "supplementary revisions of the predicted date of the end" (Towner 1984:170), found in the number 1290 and 1335 days is described by Towner (1984: 170 ) as " 43 lunar months or 3 years, 7 months" and " $44 \frac{1}{2}$ lunar months or 3 years, $8 \frac{1}{2}$ months". They are a troubled ongoing effort to handle the phenomenon of a delayed eschaton.

For Goldingay, the $3 \frac{1}{2}$ periods have some calendrical significance depending on whether the lunar calendar of the Babylonians of 354 days, the luni-solar one of the Hellenes of 360 days, the Essene solar calendar of 360 days or the one with intercalculating months bringing the calendar up to 365 days, have been used. "As Daniel's figures can be related to several calendars, so they can be related to several sets of events between 168 and 164 B.C." (Goldingay 1989:310). To him the term "final day" is the same as time of the end, not a technical term for the End. What Daniel presented was scriptural exposition but in terms not anticipated earlier in the Old Testament. Revelation' concerning the 
involvement of heavenly figures behind earthly events is something new. It was not solely prediction but promise "that shaped the identity of Jew and Christians of all shades of belief and gave them the perspective with which to view analogous crises" (Goldingay 1989:312). For Redditt (1998:200) the last chapter of Daniel presents a more precise timetable than before, "but he was less precise about what lay in future". Although Daniel talks about the end he does not make it explicit. "What he did do, however, was to retain the hope of a new day" (Redditt 1998:200).

In the commentaries on Daniel 11-12 it therefore become clear that commentator's own conceptualisation of time, world history and determinism plays an immense role in their commentaries. Some commentators are obviously more inclined towards a Westernised concept of time and history, while others are much more world and present orientated in their thoughts on Daniel's book.

\section{CONCLUSION}

It has become clear that the temporal axis of apocalypses is interpreted in many cases from a more modern Western concept of history and of time. Malina's call for a more present orientated interpretation of time as forthcoming should be implemented in the research into the book of Daniel. Not only the ideological matrix should be studied, reading the references to time in terms of Sabbaths and jubilees, but also the social matrix should be included. What does everlasting or continuing shame and contempt (Dan 12:2) mean in a society where honour and shame are so important? Or what are the implications for a person shaped by apocalyptic hope in a community where purity is important? More intensive study of the social and ideological matrix behind apocalypses as part of the spatial axis will ultimately lead to better knowledge of the temporal axis and to better understanding of apocalyptic literature. A process of what Knierim (1995:138) calls "reconceptualization" in which misconceptions coming from "misdirected postbiblical developments" should not only be recontextualized but also be rewritten, should get started.

\section{Consulted Literature}

Answers in Action: Dispensationalism Defined. http://www.answers.org/Theology/dispensationalism.html

CESNUR. Tragedy in Uganda: the Restoration of the Ten Commandments of God, a Post-Catholic Movement. http://www.religioustolerance.org also Introvugne, M 2000. Tragedy in Uganda: the restoration of the Ten Com-mandments of God, a post-Catholic movement. http://www.cesnur.org/testi/ uganda 002.htm.

Collins, A Y 1996. Cosmology and eschatology in Jewish and Christian apocalypticism. Leiden: Brill

Collins, J J 1984. Daniel with an introduction to apocalyptic literature. The forms of Old Testament literature. Volume XX. Grand Rapids: WmB Eerdmans.

,$-{ }^{2} 1998$. The Apocalyptic imagination. An introduction to Jewish apocalyptic litera- 
ture. Grand Rapids \& Cambridge: WmB Eerdmans.

Davies, P R 1993. Reading Daniel sociologically, in Van der Woude, A S (ed). The book of Daniel in the light of new findings. Leuven: Uitgeverij Peeters.

Frontline. http://www.pbs.org/wgbh/pages/frontline/shows/apocalypse/ etc/cron. html.

Goldingay, J E 1989. Daniel. Word Biblical Commentary. Dallas: Word Books. Gospel Plow. http://www.frii.net/ gosplow/index.html

Hanson, P D 1985. Apocalyptic Literature. in: Knight D A \& Tucker G M (eds), The Hebrew Bible and its modern interpreters. Philadelphia: Fortress, 465-488.

Helberg, J L 1995. The determination of history according to the book of Daniel. $Z A W$ 107: 273-287.

Knierim, R P 1995. "The Old Testament, the New Testament, and Jesus Christ", in: Knierim, R P The task of Old Testament theology: substance, method, and cases. Grand Rapids: Eerdmans.

Laato, A 1990. The seventy yearweeks in the book of Daniel. ZAW 102:212-225.

LaCocque, A 1979. The book of Daniel. London: SPCK.

Malina, B 1989. Christ and Time: Swiss or Mediterranean? CBQ 51:1-30.

Malina, B 1995. On the genre and message of Revelation: star visions and sky journeys. Peabody: Hendrickson.

Mbiti, J S 1969. African religions and philosophy. London: Heineman.

Murphy, F J 1994. Apocalypse and apocalypticism: The state of the question. Currents in Research: Biblical Studies. 2:147-179.

Planetary Groupings and the Millennium: Why Panic? http://www.skypub.com/news/special/ whypanic.html

Redditt, P L 1999. Daniel. Based on the New Revised Standard Version. New Century Bible commentary. Sheffield: Sheffield Academic Press.

Towner, W S 1984. Daniel. Interpretation. Atlanta: John Knox.

Verhoef, P A 1994. Die aanduiding van tyd in die boek Daniël. In die Skriflig 28(2):223-233.

Zahavy $T$ 1990. Apocalyptic radicalism and religion. http://www.rutgers.edu:80/zahavy/ apocalyptic.html. 